\title{
Environmental services of water resources, as part of the ocaña region city proposal
}

\section{Servicios ambientales del recurso hídrico, como parte de la propuesta de ciudad región ocaña}

\author{
José Manuel Alba-Maldonado ${ }^{*}$, Diana Milena Valdes-Solano², Sandra Durán-Durán ${ }^{3}$ \\ I*Msc. en Desarrollo Rural, jmalbam@ufpso.edu.co, ORCID: 0000-0002-5384-7606, Universidad Francisco de Paula Santander Ocaña, Ocaña, Colombia. \\ ${ }^{2}$ Msc. en Desarrollo Sostenible y Medio Ambiente, dmvaldess@ufpso.edu.co, ORCID: 0000-0002-8973-0266, Universidad Manuela Beltrán, Bucaramanga \\ Colombia. \\ ${ }^{3}$ Msc.en Gestión de Proyecto, sdurand@ufpso.edu.co, ORCID: 0000-0001-8516-6293, Universidad Francisco de Paula Santander Ocaña, Ocaña, Colombia.
}

How to cite: J. M. Alba-Maldonado, D. M. Valdes-Solano y S. Duran-Duran, "Environmental services of water resources, as part of the ocaña region city proposal". Respuestas, vol. 24, no. 2, pp. 74-80, 2019.

Received on September 20, 2018; Approved on December 03, 2018

\begin{tabular}{ll}
\hline KBSTRACT \\
\hline Keywords: & $\begin{array}{l}\text { The article establishes a conceptual framework of the Ocaña region city, taking as axis the environmental } \\
\text { services of the water resource; in this sense, a reflection is made around the city region and environmental } \\
\text { River, }\end{array}$ \\
Services, and subsequently a cartographic delimitation is made of what could be a proposal of the Ocaña \\
Environmental & Region city based on water resources through the basins where it is supplied. As a main result, a delimitation \\
services, & its use with the other municipalities, due to this, the Algodonal River is taken as the main water source of \\
Water resource. & $\begin{array}{l}\text { the city and as references, the municipalities with which the city is related, with a view to contributing to a } \\
\text { proposal of the Ocaña region city. It was possible to identify the relations of the city of Ocaña with the water } \\
\text { environmental services of the region, highlighting on the one hand its relationship with other municipalities, } \\
\text { strategic ecosystems and water basins. Cartographically delimited a proposal of city region starting from the } \\
\text { ordering of the basin of the cotton river, dividing it into high, medium and low basin. It is concluded that the } \\
\text { city of Ocaña has been built from its environmental relations with the region and that this leads to the need to } \\
\text { plan a new city model, based on the recognition and responsibility of this within a proposal of the city region. }\end{array}$
\end{tabular}

\section{RESUMEN}

Palabras clave:

Río Algodonal, Ciudad región, Servicios Ambientales, Recurso hídrico.
El artículo establece un marco conceptual de la ciudad región de Ocaña, tomando como eje los servicios ambientales del recurso hídrico; en este sentido se realiza una reflexión en torno a ciudad región y servicios ambientales, y posteriormente se realiza una delimitación cartográfica de lo que podría ser una propuesta de ciudad Región de Ocaña con base en los recursos hídricos a través de las cuencas de donde se abastece. Como principal resultado se diseñó una delimitación sobre cómo se debe entender Ocaña desde el abastecimiento hídrico y responsabilidades frente a su uso con los demás municipios, debido a ello, se toma el río Algodonal como la principal fuente hídrica de la ciudad y se toman como referentes los municipios con los que se relaciona la ciudad, con miras a contribuir a una propuesta de Ciudad Región de Ocaña. Se pudo identificar las relaciones de la ciudad de Ocaña con los servicios ambientales hídricos de la región, visibilizando por un lado su relación con otros municipios, ecosistemas estratégicos y cuencas hídricas. Se delimitó cartográficamente una propuesta de ciudad región partiendo del ordenamiento de la cuenca del rio algodonal, dividiéndola en cuenca alta, media y baja. Se concluye que la ciudad de Ocaña se ha edificado desde sus relaciones ambientales con lo región y que esto lleva a la necesidad de planificar un nuevo modelo de ciudad, partiendo del reconocimiento y responsabilidad de esta dentro de una propuesta de ciudad región. 


\section{Introduction}

The city of Ocaña is the most important urban center of the Catatumbo region, its economy, history, culture have turned it into a pole of development for the region and where commerce, public services, collection centers in front of agricultural products are concentrated.

The Municipality has an area of $627.72 \mathrm{Km}^{2}$, of which $9.34 \mathrm{Km}^{2}(1.48 \%)$ correspond to the urban sector and $618.38 \mathrm{Km}^{2}$ correspond to the rural sector [1]. This makes the city a more rural urban center than it might seem, weaving deep relationships with strategic ecosystems, water sources, agro-food supply, etc.

As the city grows and population migrations focus on the urban, greater pressures have been placed on strategic ecosystems, generating a transformation of "natural ecosystems that have been transformed into agro-ecosystems dedicated to agricultural production and that in most cases generate conflicts of land use, because of their location in fragile areas or environmental conservation" [1].

At the water resource level, Ocaña is supplied with water from the Algodonal River and the Tejo River with their respective tributaries, in addition to being receivers of wastewater discharges; thus being factors causing pollution that brings alteration and / or deterioration of quality with indirect impact on public health, development and functioning of ecosystems [2].

As a conservation strategy, an area of 2500 ha has been declared a National Protected Forest Reserve of the Upper Tejo River Basin, which is located in part of the townships of Buenavista, Agua de la Virgen and Espíritu Santo [1].

However, when it comes to the waters of the Algodonal River, its source is located in the páramo of Jurisdictions in the neighboring municipality of Abrego, and it is considered the main source of water for the towns of Ocaña and Ábrego.

This leads us to think of the city of Ocaña not only from its political-administrative borders, but also from the region with which it is in permanent interaction. The city, then, is not only understood from its geographical area, but from multiple interactions with other municipalities, which leads us to think about the region.

\section{City Region and Environmental Services}

The Region city is a response to the challenges that open in the global panorama, not only is understood as a relationship between a major city and satellite municipalities, but as an interaction between urban and rural, from where it builds economy, society, culture. Although many authors have focused on economic relations, this article aims to show how the relationship of environmental services are part of the relations between municipalities and their rural areas.

The "city-region" is understood as extended territories with links related to economic activity, history, culture and environmental resources; and where these links become socio-political forces that break with the current administrative boundaries [3].

In other words, the articulation of a city and its region form a system. This leads to consider the city as an open system and consequently it is understood that there are flows of material, energetic and informational exchanges as central elements to the dynamics of the urban and its environment [4].

For the case of this specific article we worked on the environmental relations centered on the water resource, taking as main reference the Algodonal river, which has its origin in the municipality of Abrego. These relations, however, can be framed within the environmental services used by the city of Ocaña.

Conceptually, it can be said that Environmental Services are the natural resources provided by strategic ecosystems, hydrographic basins and that they are a fundamental part of the development of diverse economic-social activities.

However, according to Espinoza [5], throughout the economic and political conceptions, environmental services have been appreciated as low-cost goods 
and in most cases of free access. For this reason, the private costs of goods and services have not reflected the true social costs of their use.

In other words, cities and economic orders have seen the wealth of rural sectors as an unlimited pantry, without any political, social and economic recognition of the populations that live there, and that in many cases they are the ones that have conserved these strategic ecosystems.

Within this framework, the need for retribution and compensation for the provision of environmental services has been raised. Where environmental service providers are compensated for the provision of such services by the beneficiaries [6] - [8].

In this way, the beneficiaries must recognize the services provided, paying the inhabitants of strategic ecosystems, in this case, for the sources of water resources in order to conserve and protect them.

The policies of the city of Ocaña, in this logic, expand territorially and would have to go beyond its political-administrative borders. In other words, in the case of water resources, policies would have to go to the municipality of Abrego, interact with it and generate proposals for the conservation and restoration of strategic ecosystems that benefit the city.

\section{Ocaña Water Resource}

The conservation of water resources has an important place within national environmental policies, especially because of their use for consumption by urban and rural populations [6].

The Algodonal river basin is located to the west of the department of Norte de Santander. It is bounded by topographical divorces and by the departmental boundary in some western sectors, corresponding to the boundaries of the municipalities of Ábrego and Ocaña [7].

The agricultural, commercial and urban infrastructure progress within the Algodonal River basin has been formed without taking into account a planning process that orients and/or projects fruitful socioeconomic and environmental activities for the region; likewise, the development process has been taking place in the region, as a response to the work and disposition of state, non-governmental and civil society entities that have tried to guide the sustainable management of the basin, but without relevant results for land use planning.

The total area of the basin is 74,639.8 hectares (ha), corresponding to $0.34 \%$ of the territory of the department of Norte de Santander; its length is 62.7 kilometers and its shape is elongated. It is located between 950 meters above sea level, at the confluence of the rivers Tejo and Algodonal, and 3,680 meters above sea level at the southern end of the basin in the sector called Páramo de Jurisdicciones [7].

At the veredal level, there are 168 trails in the basin, of which 67 partially participate and the totally included are 101, corresponding to the four municipalities of influence. The municipality of Ábrego participates with 76 trails, 26 of them partially included and the remaining 50 totally; the municipality of La Playa de Belén has 17 trails, 10 of these are partially found and only seven have all their territory within the area of the basin; the municipality of Ocaña participates with 73 trails, 29 of them partially include their territory and 44 do so totally [7].

The municipality of Ocaña is the one that requires more water to satisfy the various uses with $56.7 \%$ of total demand, indicating that it has a greater number of people settled in the basin and shows greater agricultural development, then the municipality of Ábrego with $32.3 \%$ and finally the municipality of Playa de Belén with 11.2\% [9].

Regarding the percentage distribution by municipality, the division has been made into four municipalities (Table I).

In this sense, the zone of the National Protected Forest Reserve of the Upper Algodonal River Basin (8011 ha) has been created. It is located between the sub-basins of the Frío and Oroque Rivers, tributaries of the Algodonal River, in the villages of the Paramo, breezes of Paramo, the parrot, Páez, the Slacker, the Jet, Vuelta of the María, the María, the tiger, the castle, the Ramo, the sapling and San Javier, in the municipality of Ábrego. In this reserve, the problems 
Table I. Distribution by municipality Rio Algodonal

\begin{tabular}{|c|c|c|c|c|}
\hline \multirow[t]{2}{*}{$\begin{array}{l}\text { Muni } \\
\text { cipio }\end{array}$} & \multirow{2}{*}{$\begin{array}{l}\text { Área } \\
\text { munici } \\
\text { pal } \\
\text { total } \\
\text { (ha.) }\end{array}$} & \multicolumn{2}{|c|}{$\begin{array}{l}\text { Area } \\
\text { municipal } \\
\text { dentro de la } \\
\text { cuenca }\end{array}$} & \multirow{2}{*}{$\begin{array}{l}\% \text { de la } \\
\text { cuenca en } \\
\text { territorio } \\
\text { municipa } \\
1\end{array}$} \\
\hline & & ha. & $\%$ & \\
\hline $\begin{array}{c}\text { Ábreg } \\
\mathrm{o}\end{array}$ & $\begin{array}{c}137.81 \\
9\end{array}$ & $\begin{array}{c}42.50 \\
1\end{array}$ & 30,8 & 56,9 \\
\hline $\begin{array}{c}\text { La } \\
\text { Playa } \\
\text { de } \\
\text { Belén }\end{array}$ & $\begin{array}{c}24.109 \\
1\end{array}$ & $\begin{array}{c}4.543 \\
6\end{array}$ & 18,8 & 6,1 \\
\hline $\begin{array}{c}\text { Teora } \\
\text { ma }\end{array}$ & $\begin{array}{c}93.010 \\
1\end{array}$ & 158,3 & 0,2 & 0,2 \\
\hline $\begin{array}{c}\text { Ocañ } \\
\mathrm{a}\end{array}$ & $\begin{array}{c}64.223 \\
3\end{array}$ & $\begin{array}{c}27.43 \\
6\end{array}$ & 42,7 & 36,8 \\
\hline
\end{tabular}

Source: [7]

begin to be generated by the indiscriminate cutting down of plant species for the establishment of pastures in hillside and slope zones [10].

Water from the Algodonal River is considered the main source of water for the population of the municipalities of Abrego and Ocaña de Norte de Santander, being a water source susceptible to processes of water pollution, which is exerting a strong pressure on its quality, as it is the receiving body of all types of dumping without any prior treatment. The monitors from Ábrego to the entrance to the municipality of Ocaña show a condition of low contamination by periodic suspended solids in all sampling stations, which represents that the Algodonal river manages to completely self-purify from the constant contribution coming from the discharges of residual and domestic waters [2].

Parallel to the previous research [11], they perform microbiological analyses from Ábrego to the entrance of Ocaña; according to the results of evaluation of microbiological quality based on Box-plot Diagrams, they conclude that the results are below the maximum allowed values of the regulations, this means that within the sampling section the quality of raw water is suitable for human consumption prior to an appropriate treatment of potabilization.
The water potential of the Algodonal river basin is delimited according to the supply and demand of water, this presents restrictions in its benefit by the anthropic variation that has developed the direct effects on the hydrological cycle, specifically on the quality and quantity of the resource, because there are patterns of use characterized by mechanisms of inefficient use of the resource and the incorporation of waste to the water source.

This panorama is reflected in the city of Ocaña since for several years there has been an environmental problem due to the contamination of its water bodies and that currently no mathematical models have been used to manage water quality, nor have detailed studies of physicochemical and microbiological variables [12]. According to the authors, with the analyses of the contamination indexes (ICOs) they observed a great incidence of contamination by organic matter, as well as of conductivity, which confirms contamination by dumping ions; these analyses were carried out from the birth of the river Tejo and river Chiquito in the city of Ocaña to the exit of the municipality. It is important to point out that in its first section the river does not receive pollution from care, but as the river moves through the city its situation is affected by the sewage from the sewers of Ocaña and Rio de Oro and other pollutants of urban and rural origin [13].

With regard to the environmental impact of Ocaña against the municipalities of the lower basin of the Algodonal Carmen River: Convención, Teorama, San Calixto and the Tarra, for contaminating contributions to the water resource; so far no publications have been made on the subject, which opens new perspectives in the development of future research.

\section{Proposal for the City of Ocaña Region from the point of view of water resources}

The strategic location of the Municipality of Ocaña, due to its proximity to the binational basin, makes it a site of forced passage, provider of goods and services. Among its main hydrographic resources we will mention the following: The Tejo River runs from South to North in the urban area of the 
municipality; the Chiquito River and the Algodonal River, tributaries of the Catatumbo River Basin [14].

Taking into account the above, a cartographic proposal of the City Region of Ocaña has been designed based on environmental services, where the main water source of the region is taken as the territorial boundary. In this sense, they were delimited based on the upper watershed, as a provider of environmental services and where payments for environmental services must be assumed in front of the municipality of Abrego and the zone of the National Protective Forest Reserve of the Upper Watershed of the Algodonal River.

As far as the Algodonal river basin is concerned, a division was made into upper, middle and lower basins. The upper basin corresponds to the birth in the zone of the National Protective Forest Reserve Upper Basin of the Algodonal River.

The ecosystems present in the Upper Basin of the Algodonal River are strategic, mainly the areas of births such as the Páramo de Jurisdicciones, the main fluvial star that supplies veredales and municipal aqueducts in the province of Ocaña, where there is constant pressure on the natural forest, representing a selective looting of commercial timber or total logging to expand the agricultural and livestock frontier [9].

The City Region of Ocaña would assume the costs of environmental services, recognizing that despite the fact that the water supply is not located in its territory, it is there where its policies and expanded and inclusive land-use plans must be aimed in relation to other municipalities. In this way, the City Region of Ocaña interacts with other municipalities and ecosystems, in this case the municipality of Abrego as the source and source of the water resource from which it is supplied (Figure I).

Regarding the middle part of the Basin, the city Region of Ocaña, the water resource would have a relationship with the municipalities of La Playa, San Calixto and Convención. From this projection the Algodonal River would be a fundamental part of the environmental services and would have to be a reference to trace a part within the regional project. (Figure I)

Regarding the lower Algodonal River basin, the negative impacts on the Algodonal River basin play a fundamental role, due to the contribution of pollution from the city of Ocaña to the water resource. The municipalities that would be impacted would be Carmen, Convención, Teorama, San Calixto and Tarra. (See figure I)

The city Region of Ocaña, is built from environmental services to sustain its economy and the societies inserted in the urban zone, in this sense it is necessary to make visible the relations with the region, for this specific case the hydric resource has been taken, as fundamental part to understand Ocaña, from its relation with the region. Not only with the environmental services from which it benefits, but also with the impacts generated by their use.

The construction of the city region proposal from Environmental Services of water resources leads from the cartographic proposal to interactions with territories, municipalities and societies that go beyond their borders.

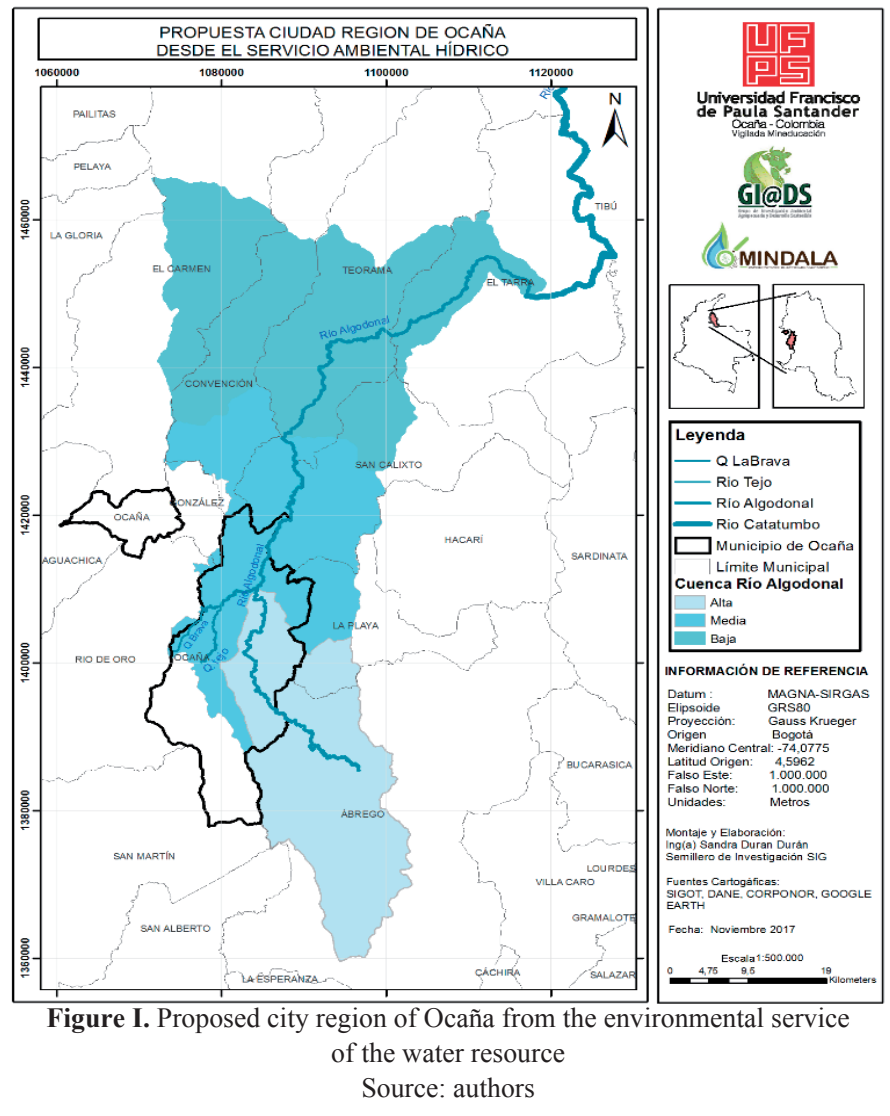




\section{Conclusions}

The Ocaña City Region proposal makes visible the relations with the environmental services of the city and its region. Identifying the main water source of the city as the Algodonal river, which leads to propose environmental policies that break the classic structure of the city and reconstitute it in intimate relations with rural sectors of other municipalities.

In the case of the cotton river, the upper, middle and lower river basins were delimited. For the upper basin, environmental services were identified that should be considered from Ocaña as retribution policies for the inhabitants of the National Protective Forest Reserve of the Algodonal River upper basin of the municipality of Abrego. As far as the middle basin is concerned, it is necessary to generate policies of urban rural integration, for the conservation of the quality of the water resource from which the city is supplied, and lastly in front of the lower basin, it is necessary to carry out studies on the polluting load that the city of Ocaña contributes to the municipalities that are part of this sector of the river and to assume environmental responsibilities.

The proposal of city Region of Ocaña from the environmental services lead to think the city in another perspective in relation to the services, the impacts that are generated and that have built the city to economic, social and cultural level, making visible unknown and hidden aspects from the asymmetric urban-rural dynamics. It is necessary to carry out specific studies in terms of quantification of services and environmental costs, as well as negative impacts of the city with the region at the level of pollution.

The city of Ocaña is more City Region than is thought, its relationship with the Catatumbo, its towns, its rural areas, strategic ecosystems and water basins have built it through history and have allowed it to be the most important city in this region of the country.

\section{Reference}

[1] Municipality of Ocaña, "Development Plan of the Municipality of Ocaña 2016-2019", Ocaña: Municipality of Ocaña, 2016.
[2] R. Ramírez and E. Sánchez, "Evaluación de la calidad del agua para consumo humano mediante indicadores físicoquímicos y microbiolgógicos del río Algodonal", Ingenuity, vol. 9, pp. 131-141, 2016.

[3] L. Pinzón-Hernández, "Regarding city-region process in Medellin - metropolitan area (2010-2011)", Academia y Virtualidad, vol. 5, no. 1 , pp. 123-141. 2012

[4] S. Boisier, "Some reflections to approach the concept of city-region", Social Studies, vol. 15, no. 28, pp.164-190, 2006.

[5] E. Espinoza, "El pago de servicios ambientales y el desarrollo sostenible en el medio rural", Publicaciones Ruta, 1999.

[6] J. Granadillo, "Entomofauna bioindicadora del río Algodonal, La Ermita, Norte de Santander", Ingenio, pp. 112-117, 2013.

[7] CORPONOR, "Plan for the Management and Environmental Management of the Algodonal River Basin Ocaña”, CORPONOR, 2007.

[8] S. Pagiola, "Payments for Environmental Services", Environment Strategy, 2010. http:// www.katoombagroup.org/documents/cds/ redlac_2010/resources/pagiola. pdf

[9] Municipality of Ocaña, "National Campaign Water is a public good, let's reconnect with our Algodonal river", 2015.

[10] Association of municipalities of Catatumbo, "Province of Ocaña and South of Cesar. Regional Agenda for Sustainable Development Catatumbo, Province of Ocaña and South of Cesar (Río de Oro - González)", Association of municipalities of Catatumbo, 2014.

[11] R. Miranda, R. Ramírez and W. Angarita, "Microbiological analysis of the water quality of the Algodonal river in the stretch between the municipalities of Ábrego and Ocaña Norte de Santander”, Ingenio, pp. 189-200, 2016. 
[12] I. Díaz, H. Quintero, Y. Lozano, L. Fonseca and D. Valdes, "Ríos Tejo and Chiquito: Evaluation of the ICOs within the urban structure of Ocaña, Norte de Santander", Ingenio, pp. 213$221,2017$.

[13] J. Meléndez, "Alto Catatumbo: region and environment”, Bogotá: Codex Ltda, 1999.

[14] L. Aguilera, "Plan de manejo ambiental de la reserva forestal protectora nacional cuenca hidrográfica del río Tejo”, Ocaña, 2005. 